\title{
Amyloid- $\beta$ Levels in Mice Hippocampus According to the ALDH2 Enzyme Activity followed Ethanol Exposure for 8-Weeks
}

\author{
Sun-In Moon, Sang-Yong Eom, Dong-Hyuk Yim, Sun-Ho Song, Yong-Dae Kim* and Heon Kim \\ Department of Preventive Medicine, College of Medicine and Medical Research Institute, Chungbuk National University, Cheongju 361-763, \\ Korea
}

Received September 6, 2011 /Revised November 13, 2011 /Accepted November 16, 2011

\begin{abstract}
Alzheimer's disease (AD) is a progressive neurodegenerative disease, resulting in the loss of cognitive function. Mitochondrial aldehyde dehydrogenase (ALDH2) has been proposed to be a risk factor for the development of $\mathrm{AD}$, but there is still controversy about that. In this study, we demonstrated the role of ALDH2 enzyme activity on amyloid-beta $(\mathrm{A} \beta)$ and nuclear factor kappa B (NF- $\mathrm{B}$ ) expression in mice brain following ethanol exposure for 8 weeks. Five male Aldh2 $(+/+)$ and Aldh2 (-/-) mice, 8 weeks-old of age (C57BL/6J strain), in each group were exposed to ethanol for 8 weeks $(2 \mathrm{~g} / \mathrm{kg}$ wt./day) using gavage. Those in the control groups received $0.9 \%$ saline alone. Results showed a difference in expression level of $A \beta$ in the hippocampus after ethanol exposure according to the ALDH2 enzyme activity $(p<0.05)$, but not in the level of NF-kB. Our results suggest a possibility that ALDH2 enzyme activity may be an important role in the development of $\mathrm{AD}$.
\end{abstract}

Key words : Aldehyde dehydrogenase 2, Alzheimer disease, hippocampus, amyloid-beta, nuclear factor $\mathrm{kB}$

\section{서 론}

알츠하이머 질환(Alzheimer's disease)은 인지능력과 행동 능력 두 가지에 모두 영향을 미치는 진행적 노인성 치매증의 일종으로 정확한 발병기전은 아직 알려져 있지 않으나 복잡한 신호전달체계(signal transduction)를 통해 뇌의 해마조직 부 위에 아밀로이드 베타(amyloid-beta, $\mathrm{A} \beta$ )가 다량 축적되고 이 로 인해 뇌세포의 사멸(apoptosis)이 유도되는 것으로 알려져 있다 $[19,21,25]$. 또한, 이 과정에 활성산소(Reactive oxygen species, ROS) 생성을 통한 산화적 스트레스가 중요한 역할을 할 가능성이 매우 크다[3,4,16].

뇌조직에서의 산화적 스트레스 발생은 매우 다양한 생리적 변화를 유도하는데 그 중 하나가 전사인자로 잘 알려진 nuclear factor $\kappa \mathrm{B}(\mathrm{NF}-\kappa \mathrm{B})$ 의 억제이다. 세포질 내에 존재하는 $\mathrm{NF}-\kappa \mathrm{B}$ 는 I- $\kappa \mathrm{B}$ 와 결합하여 비활성화의 형태를 유지하다가 일 련의 신호전달 반응에 의해 $\mathrm{I}-\mathrm{kB}$ 로부터 분리가 되면 활성화되 어 핵 내로 유입되며 특정 유전자의 발현에 영향을 주어 생리 적 반응을 조절하는 것으로 알려져 있다[12,14]. 알츠하이머 환자들의 경우, 이러한 NF- $\mathrm{NB}$ 의 활성 조절에 이상이 있는 것 으로 알려져 있으며 Altura 등[2]에 의하면 에탄올 투여가 뇌 조직의 NF-kB 활성에 영향을 주고 이것이 알코올 기인성 뇌손 상과 관련이 있다고 보고한 바 있다.

알츠하이머 질환은 환경적인 요인 이외에도 유전적인 요소

*Corresponding author Tel: +82-43-261-2845, Fax: +82-43-274-2965

E-mail : ydkim@chungbuk.ac.kr
가 중요한 위험인자로 알려져 있는데 그 중 하나가 알데히드 탈수소효소 2(aldehyde dehydrogenase 2; ALDH2) 유전자이 다. 체내에 유입된 에탄올은 알코올 탈수소효소(alcohol dehydrogenase; $\mathrm{ADH}$ )에 의해 아세트알데히드로 대사된 후 다 시 알데히드탈수소효소 2(aldehyde dehydrogenase 2; $\mathrm{ALDH} 2$ )에 의해 아세트산으로 대사되어 배출된다[1]. 우리나 라를 포함한 동양인의 약 $40-50 \%$ 정도는 $\mathrm{ALDH} 2$ 효소의 활성 이 저하된 유전자형을 가지고 있는 것으로 알려져 있다[7,8]. 에탄올의 대사과정 중에는 다량의 활성산소(free radical)가 생 성되어 체내에서 산화적스트레스를 유발하는 것으로 알려져 있고 $[3,9,13,16]$, 알코올의 급성 투여가 활성산소의 생성을 증 가시킨다는 보고도 있다[4,18]. 따라서 ALDH2 효소의 활성은 알코올 섭취에 의한 활성산소의 생성과 이에 따른 질병 발생 과정에서 중요한 역할을 할 가능성이 높으며, 실제로 $\mathrm{ALDH} 2$ 활성이 저하된 경우는 그렇지 않은 경우에 비해 특정 질병의 발생률이 유의하게 높은 것으로 알려져 있다[22]. 알코올의 과 다 노출 및 반복적인 복용은 알츠하이머 질환의 중요한 위험 인자 중 하나로 알려져 있으며, Ohta 등[17]이 일본인을 대상 으로 시행한 역학연구에 따르면 ALDH2 효소의 활성이 알츠 하이머 질환의 발생에서 매우 중요한 역할을 한다고 보고하고 이 기전에 산화적스트레스가 관여하고 있음을 제시하였다. 그 러나 한국인을 대상으로 한 Shin 등[20]의 연구에서는 ALDH2 효소의 유전자다형성이 알츠하이머 발생과 관련이 없다고 보 고하였으며, 몽골인을 대상으로 한 Zhou 등[26]의 연구에서도 $\mathrm{ALDH} 2$ 유전자 다형성은 알츠하이머 질환 발생과 관련성이 없다고 보고하여 $\mathrm{ALDH} 2$ 유전자 다형성과 알츠하이머 질환 
과의 관련성은 현재까지도 많은 논란이 되고 있다.

본 저자 등은 이상의 결과들을 토대로, 반복적인 알코올 복용에 의한 알츠하이머 질환의 발생에서 $\mathrm{ALDH} 2$ 효소의 활 성이 어떠한 영향을 주는지 파악하기 위하여 $\mathrm{ALDH} 2$ 효소가 결핍된 유전자변형 마우스에 8주간 에탄올을 경구 투여한 후 뇌조직을 분리하여 알츠하이머 질환의 지표로 잘 알려진 아 밀로이드 베타의 발현과 NF- $\mathrm{NB}$ 의 발현을 평가하고 이러한 변화가 ALDH2 효소의 활성에 따라 어떻게 달라지는지 비교 하였다.

\section{재료 및 방법}

\section{실험 동물}

Aldh2 (-/-) 마우스[13]를 일본의 Kawamoto 교수로부터 분 양받아 실험에 사용하였다. 12주령의 수컷 $A l d h 2(+/+)$ 및 Aldh2 (-/-) (C57BL/6J strains)를 플라스틱 마우스 케이지에서 12시간(07:00 19:00)은 밝게, 나머지 12시간(19:00 07:00)은 어 두운 상태로 유지시켰으며 배양실의 온도는 $23 \sim 25^{\circ} \mathrm{C}$ 를 유지 하였다. 동물실험과 관련된 모든 조작은 'Guide for the Care and Use of Laboratory Animals prepared by the National Academy of Sciences and published by the National Institutes of Health'의 규정에 따라 시행하였으며 동물의 배 양과 투약 및 모든 과정은 엄격한 무균환경(SPF) 하에서 이루 어졌다. 또한, 실험시작 전에 본 기관의 동물실험지원센터로 부터 연구의 윤리성에 대한 승인을 얻었다(CBNU-0340902-01).

\section{A/dh2 유전자형 분석 및 에탄올 투여}

마우스 꼬리부분에서 genomic DNA를 추출하여 PCR 증폭 방법으로 Aldh2 유전자형을 결정하였다[10]. 각 군에 5마리씩 의 마우스를 배정하여 알코올 투여군에는 $20 \%$ 에탄올 $(2$ $\mathrm{g} / \mathrm{kg} /$ day)을 8주간 매일 1회 경구 투여(oral gavage)하였다. 투여기간 동안 먹이 섭취는 제한하지 않았다.

\section{마우스의 해마조직에서 아밀로이드 베타 발현 측정}

8주간의 투여가 끝난 후 마우스는 케타민/자일라진(10:1)을 통해 마취시킨 후 신속하게 뇌를 분리하였고 해마조직을 따로 적출하여 즉시 액체질소에 넣은 후 실험에 사용할 때까지 -8 $0^{\circ} \mathrm{C}$ 에서 보관하였다. 분리한 해마조직을 TBS $(50 \mathrm{mM}$ Tris- $\mathrm{HCl}, \mathrm{pH}$ 7.4)에 $0.5 \mathrm{mM}$ PMSF (phenylmethylsulfonyl fluoride) 와 $2 \mathrm{mM}$ EDTA가 첨가된 완충액에 넣고 균질화 (homogenization) 시킨 후 SDS의 농도가 $0.6 \%$ 가 되도록 넣은 다음 잘 섞어주고 초고속 원심분리(Bekman Coulter, Fullerton, California)를 사용하여 $300,000 \times g$ 로 한 시간 원심 분리 후 상층액을 실험에 사용하였다. 아밀로이드 베타 발현 의 측정은 시판되는 BetaMarkTM Beta-Amyloid x-42 ELISA kit (Covance, Emeryville, California)를 사용하여 제조사의 설 명서에 따라 시행하였다. 플레이트에 세척액 $300 \mu \mathrm{l}$ 를 넣고 세척한 다음 표준용액과 샘플을 각각 $100 \mu 1$ 씩 넣고 $2 \sim 8^{\circ} \mathrm{C}$ 에서 밤새 배양하였다. 다음날 내용물을 제거한 후 세척액 $300 \mu 1$ 로 세척하고 기질 $100 \mu \mathrm{l}$ 를 추가한 후 15 초간 가볍게 흔들어 발광 분석기(luminometer)로 발현정도를 측정하였다. 단백정량은 Bradford assay를 통해 시행한 후 보정하였다.

\section{뇌조직에서의 $\mathrm{NF}-\mathrm{\kappa B}$ 발현 측정}

분리한 뇌 조직으로부터 핵 단백질(nuclear extracts)을 분 리하여 실험에 사용하였다. 분해용액 $(50 \mathrm{mM} \mathrm{KCl}, 0.5 \%$ NP-40, pH 7.825 mM HEPES, 1 mM PMSF, $10 \mu \mathrm{g} / \mathrm{ml}$ leupeptin, $20 \mu \mathrm{g} / \mathrm{ml}$ aprotinin, $100 \mu \mathrm{M}$ DTT) $1.5 \mathrm{ml}$ 에 조직을 넣고 균질화(homogenization)시킨 후 얼음에 15 분간 방치하 였다. $850 \times \mathrm{g}, 4^{\circ} \mathrm{C}$ 에서 10 분간 원심분리 후 상층액을 버리고 분해용액 $1.5 \mathrm{ml}$ 을 넣고 다시 균질화시킨 후 15 분간 얼음에 방치하였다. 새 튜브에 시료를 옮겨 담은 후 $14,000 \times \mathrm{g}, 4^{\circ} \mathrm{C}$ 에 서 3 분간 원심분리하고 상층액(cytosolic fraction)은 따로 보관 하였으며 침전물에 추출용액 $(500 \mathrm{mM} \mathrm{KCl}, 10 \%$ glycerol, 25 mM HEPES, 1 mM PMSF, $10 \mu \mathrm{g} / \mathrm{ml}$ leupeptin, $20 \mu \mathrm{g} / \mathrm{ml}$ aprotinis, $100 \mu \mathrm{M}$ DTT) $150 \mu \mathrm{l}$ 를 넣은 후 10 초간 강하게 교반 하였다. 얼음에 60 분간 방치 후 20 분 정도 가볍게 두드려주고 $14,000 \times \mathrm{g}, 4^{\circ} \mathrm{C}$ 에서 5 분간 원심분리하여 새 튜브에 상층액을 분리하였다.

전사인자 NF-kB 측정은 Procarta Transcription Factor Plex Kit (Panomics, Dumbarton Circle, Fremont)를 가지고 제품의 설명서에 따라 시행하였다. 준비된 PCR 플레이트에 대조액

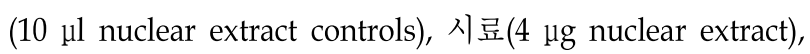
보정액(blank) (5 $\mu \mathrm{l}$ working B reagent, $5 \mu \mathrm{l}$ nuclease-free distilled water)와 $10 \mu \mathrm{l}$ 검출 탐침(probe)을 각각 넣어주었다. 알 루미늄 덮개로 플레이트를 덮고 가볍게 섞어준 후 $\mathrm{PCR}$ 기계 를 사용하여 $15^{\circ} \mathrm{C}$ 에서 30 분간 배양하였다. 키트에 포함된 플 레이트 위에 분리판을 놓고 결합용액 $180 \mu 1$ 를 넣은 후 $564 \times$ $g, 4{ }^{\circ} \mathrm{C}$ 에서 2 3분간 원심분리하였다. 단백질-DNA 복합체가 있는 PCR 플레이트에 $20 \mu \mathrm{l}$ 결합용액을 넣은 후 미리 적신 분리판에 각각 $30 \mu \mathrm{l}$ 씩 옮기고 30 분간 얼음에 방치하였다. 분 리판에 $180 \mu \mathrm{l}$ 분리용액을 넣고 5 분간 얼음에 방치한 후 $563 \times$ $g, 4^{\circ} \mathrm{C}$ 에서 2 3분간 원심분리 하였다. 아래 위치한 플레이트의 내용물을 버리고 같은 방법으로 4 번 반복하여 세척한 후 마지 막에 $563 \times \mathrm{g}, 4^{\circ} \mathrm{C}$ 에서 3 분간 원심분리를 추가로 실시하였다. 분리판에 $60 \mu \mathrm{l}$ 추출용액을 각각 추가하고 알루미늄 덮개를 사용하여 플레이트를 덮은 후 키트내 포함된 시료 수집 플레 이트 위에 위치시킨 후 실온에서 5 분간 배양하였다. 플레이트 를 $563 \times g$ 에서 3 분간 원심분리 하여 시료 수집 플레이트에 내용물을 수집하였다. 알루미늄 덮개를 PCR 플레이트 덮개로 교체한 후 $\mathrm{PCR}$ 기계를 사용하여 $95^{\circ} \mathrm{C}$ 에서 5 분간 변성시킨 
후 다음 단계까지 최소 5 분간 얼음에 방치하였다. 키트 내 포 함된 거름판을 플레이트 위에 놓은 후 $150 \mu \mathrm{ll}$ 세척용액을 추가 하여 실온에서 5 분간 배양하였다. 진공을 사용하여 거름판 내 세척용액을 제거하고 30 초간 고속으로 교반한 구슬(capture bead)을 $50 \mu 1$ 씩 추가하였다. $40 \mu \mathrm{l}$ 측정 용액(assay buffer)을 거름판에 추가한 후 얼음에 방치된 시료를 각각 $30 \mu \mathrm{l}$ 씩 거름 판으로 옮기고 $500 \mathrm{rpm} 50^{\circ} \mathrm{C}$ 에서 30 분간 배양하고 발광분석 기로 측정한 후 TFIID (transcription factor IID)를 측정하여 값을 보정하였다.

\section{통계분석}

통계분석은 윈도우용 SPSS (Version 12.0)를 사용하였다. 아 밀로이드 베타 및 NF-kB의 발현이 에탄올 복용 여부와 $\mathrm{ALDH} 2$ 효소의 활성에 따라 차이를 보이는지 검정하기 위하 여 2-way ANOVA를 이용하였으며 p-값이 0.05 이하인 경우 를 유의한 것으로 판정하였다.

\section{결과 및 고찰}

알츠하이머 질환은 다양한 유전적, 환경적 요인이 복합적으 로 관여하는 대표적인 만성 뇌신경질환으로 과다한 알코올 섭취가 매우 중요한 위험요인 중 하나로 알려져 있다[6,11]. 본 연구에서는 8 주간 에탄올을 투여한 마우스의 해마조직에 서 알츠하이머 질환의 대표적인 생물학적 지표인 아밀로이드 베타의 양을 측정하여 비교하였다. 그 결과, Aldh2 (+/+) 마우 스의 경우 8 주간의 에탄올 투여에 의해 해마조직의 아밀로이 드 베타 양이 거의 변화하지 않은 반면, Aldh2 (-/-) 마우스의 경우는 에탄올 투여 전과 비교하여 $24.29 \%$ 의 증가를 보인 것 으로 나타났다(Fig. 1). 에탄올 투여와 ALDH2 유전자형 중 아밀로이드 베타 농도에 영향을 준 인자가 무엇인지 알아보기

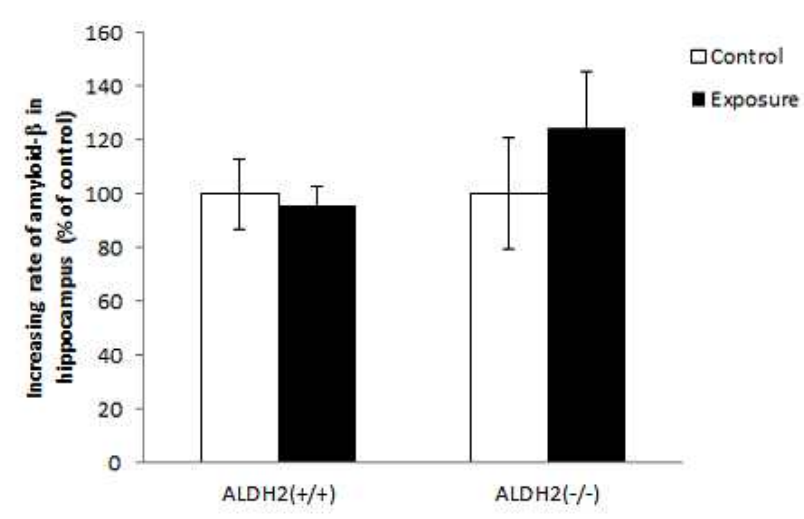

Fig. 1. Amyloid-beta level in hippocampus of mice treated with saline or $2 \mathrm{~g} / \mathrm{kg} /$ day of ethanol for 8 weeks. Five different brains for each treatment group were individually analyzed by ELISA kit. Error bar represents standard error in each group.
위하여 2-way ANOVA를 이용하여 분석한 결과, ALDH2 효 소의 활성이 통계적으로 유의하게 아밀로이드 베타 농도에 영향을 준 것으로 나타났다( $p<0.05)$ (Table 1). 본 연구진은 선 행연구를 통하여 고농도의 급성 에탄올 투여 및 8 주간의 반복 투여가 마우스의 소변에서 산화적 스트레스를 유발하고 특히, $\mathrm{ALDH} 2$ 효소가 결핍된 경우에 그 정도가 더욱 심하다는 것을 보고한 바 있다[15]. 이상의 연구결과들은 반복적인 에탄올 노 출이 산화적 스트레스의 발생을 증가시키고 이로 인해 뇌조직 에서의 아밀로이드 베타의 축적 및 알츠하이머 질환의 발생에 서 $\mathrm{ALDH} 2$ 효소의 활성이 매우 중요한 역할을 할 가능성을 시사해준다. ALDH2 효소의 유전자 다형성과 알츠하이머 질 환과의 관련성에 대해서는 아직까지도 많은 논란이 있으나 지금까지 이와 관련된 연구가 대부분 역학연구라는 점에서 본 동물연구의 결과는 더욱 중요한 의미를 가질 수 있다 $[17,23,24,26]$. 왜냐하면, 역학연구의 특성상 알츠하이머 질환 의 발생과 관련이 있는 다양한 인자들을 모두 통제하기가 현 실적으로 불가능하기 때문이다.

한편, 알츠하이머 질환을 비롯한 퇴행성 뇌신경질환의 발생 에서 제시되고 있는 또 하나의 기전은 NF-kB를 통한 신경세포 의 사멸이다. 정상적인 상태에서는 억제되어 있던 NF-kB가 활성화되면서 신경세포의 사멸을 유도하고 이를 통해서 알츠 하이머 질환이 유발된다는 것이다 $[2,5,12,14]$. 그러나 아직까지 이 과정에 $\mathrm{ALDH} 2$ 효소의 활성이 어떤 역할을 하는지에 대한 연구는 보고된 바 없다. 본 저자 등은 8주간 에탄올을 투여한 마우스의 뇌조직으로부터 세포핵 내에 존재하는 NF-kB를 정 량하고 이를 그룹별로 비교해 봄으로써 에탄올에 의한 NF-kB 의 발현에 $\mathrm{ALDH} 2$ 효소가 어떤 역할을 하는지 알아보고자 하였다. 그 결과, Aldh2 (+/+) 군의 경우는 NF-kB의 농도가 에탄올 투여 전과 전혀 차이가 나지 않았으며, Aldh2 (-/-) 군의 경우 투여 전 농도의 $96.14 \%$ 를 나타내 소량의 감소는 있었으 나 통계적으로 유의한 차이는 아닌 것으로 나타나 에탄올에 의한 NF-kB의 농도 증가와 $\mathrm{ALDH} 2$ 효소와의 관련성을 확인 할 수 없었다(Fig. 2, Table 1). 이러한 결과는 에탄올의 만성 노출에 의한 알츠하이머 질환에서 NF-kB의 역할이 그다지 중 요한 역할을 하지 않을 가능성도 생각할 수 있으나 본 연구가

Table 1. Analysis of variance (2-way ANOVA) of the effects of the Aldh2 genotype and ethanol exposure on the amyloid-beta level in hippocampus and NF-kB level in brain tissue

\begin{tabular}{lcc}
\hline Variables & $\begin{array}{c}\text { Amyloid-beta level } \\
\text { in hippocampus }\end{array}$ & $\begin{array}{c}\text { NF-kB level in } \\
\text { brain }\end{array}$ \\
\hline \multirow{2}{*}{ Aldh2 genotype } & $\mathrm{F}=8.344$ & $\mathrm{~F}=0.158$ \\
& $p<0.05$ & $\mathrm{~N} . \mathrm{S}$ \\
\hline \multirow{2}{*}{ Ethanol exposure } & $\mathrm{F}=0.173$ & $\mathrm{~F}=0.049$ \\
& $\mathrm{~N} . \mathrm{S}$ & $\mathrm{N} . \mathrm{S}$ \\
\hline
\end{tabular}

N.S: not significant 


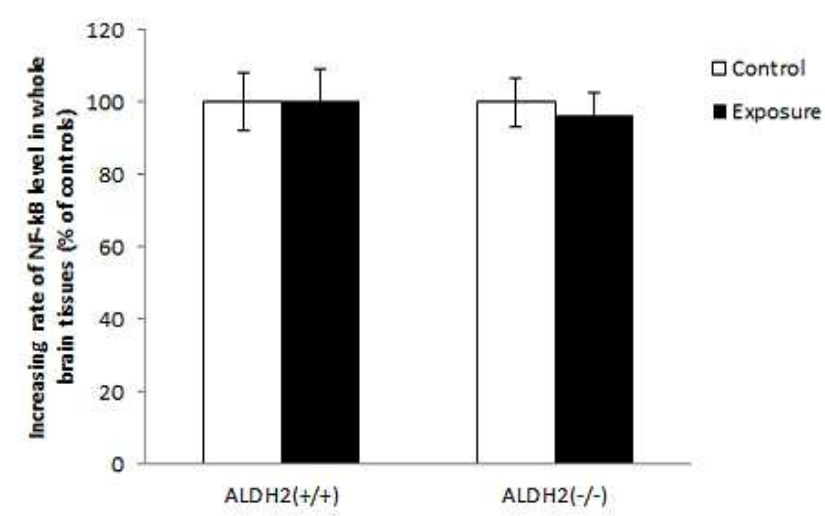

Fig. 2. NF- $\mathrm{kB}$ level in brain of mice treated with saline or 2 $\mathrm{g} / \mathrm{kg} /$ day of ethanol for 8 weeks. Five different brains for each treatment group were individually analyzed by commercially available kit. Error bar represents standard error in each group.

기존의 연구와는 달리 저농도 에탄올을 이용한 in vivo 연구였 다는 점과 비록 통계적인 유의성은 없었지만 Aldh2 (-/-)에서 만 NF-kB 의 발현농도가 감소한 본 연구의 결과를 비추어 볼 때, 본 연구에서 사용한 에탄올의 농도가 NF-kB 발현에 필요 한 농도에 미치지 못했을 가능성도 배제할 수 없다. 이를 확인 하기 위해서는 다양한 농도 및 기간에 대한 추가 연구가 필요 할 것으로 생각된다.

본 연구가 군당 마우스의 수가 충분치 않았고 에탄올의 농 도를 한가지로만 사용한 점 등의 한계를 가지고 있는 예비연 구(pilot study)이기는 하나 에탄올에 의한 알츠하이머 질환의 발생에서 ALDH2 효소의 활성이 어떤 역할을 하는지를 규명 하기 위해 aldh 2 유전자변형 마우스를 이용한 최초의 연구라 는 점에서 그 의의를 찾아볼 수 있다.

요약하면, 8주간 에탄올을 경구 투여한 마우스에서 ALDH2 효소의 활성은 뇌조직의 아밀로이드 베타 축적에 중요한 영향 을 미치는 것으로 확인되었다. 본 연구의 결과는 $\mathrm{ALDH} 2$ 효소 가 결핍된 사람은 결핍되지 않은 사람에 비해 아밀로이드 베 타의 축적이 상대적으로 많이 발생할 수 있으므로 결과적으로 알코올에 의한 알츠하이머 질환 발생에 더욱 민감할 수 있음 을 시사한다.

\section{감사의 글}

이 논문은 2007년 정부(교육과학기술부)의 재원으로 한국 연구재단의 지원을 받아 수행된 연구이며(KRF-2007-313$\mathrm{E} 00181)$, 이에 감사 드립니다.

\section{References}

1. Agarwal, D. P. and H. W. Goedde. 1992. Pharmacogenetics of alcohol metabolism and alcoholism. Pharmacogenetics 2,
48-62.

2. Altura, B.M. and A. Gebrewold. 1998. Pyrrolidine dithiocarbamate attenuates alcohol-induced leukocyte-endothelial cell interaction and cerebral vascular damage in rats: possible role of activation of transcription factor NF-kappaB in alcohol brain pathology. Alcohol 16, 25-28.

3. Bondy, S. C. 1992. Ethanol toxicity and oxidative stress. Toxicol. Lett. 63, 231-241.

4. Bondy, S. C. and J. Orozco. 1994. Effects of ethanol treatment upon sources of reactive oxygen species in brain and liver. Alcohol Alcohol. 29, 375-383.

5. Camandola, S., P. Giuseppe, and M. P. Mattson. 2000. The lipid peroxidation product 4-hydroxy-2,3-nonenal inhibits constitutive and inducible activity of nuclear factor $\mathrm{kB}$ in neurons. Mol. Brain Res. 85, 53-60.

6. Fadda, F. and Z. L. Rossetti. 1998. Chronic ethanol consumption:from neuroadaptation to neurodegeneration. Prog. Neurobiol. 56, 385-431.

7. Goedde, H. W., D. P. Agarwal, S. Harada, D. Meier-Tackmann, D. Ruofu, and U. Bienzle. 1983. Population Genetic studies on aldehyde dehydrogenase isozyme deficiency and alcohol sensitivity. Am J. Hum Genet. 35, 769-772.

8. Goedde, H. W., D. P. Agarwal, G. Fritze, D. Meier-Tackmann, S. Singh, and G. Beckmann. 1992. Distribution of ADH2 and ALDH2 genotypes in different populations. Hum Genet. 88, 344-346.

9. Ishii, H., I. Kurose, and S. Kato. 1997. Pathogenesis of alcoholic liver disease with particular emphasis on oxidative stress. J. Gastroenterol. Hepatol. 12, 272S-282S.

10. Isse, T., T. Oyama, T. Kitagawa, K. Matsuno, A. Matsumoto, and A. Yoshida. 2002. Diminished alcohol preference in transgenic mice lacking aldehyde dehydrogenase activity. Pharmacogenetics 12, 621-626.

11. Jaatinen, P. and J. Rintala. 2008. Mechanisms of ethanol-induced degeneration in the developing, mature, and aging cerebellum. Cerebellum 7, 332-347.

12. Kaur, J. and M. P. Bansal. 2008. Effect of vitamin E on alcohol-induced changes in oxidative stress and expression of transcription factors NFkappaB and AP-1 in mice brain cerebral hemispheres. Indian J. Exp. Biol. 46, 562-567.

13. Kitagawa, K., T. Kawamoto, N. Kunugita, T. Tsukiyama, K. Okamoto, and A. Yoshida. 2000. Aldehyde dehydrogenase (ALDH) 2 associates with oxidation of methoxyacetaldehyde; in vitro analysis with liver subcellular fraction derived from human and Aldh2 gene targeting mouse. FEBS Lett. 476, 306-311.

14. Meffert, M. K. and B. David. 2005. Physiological functions for brain NF-kB. Trends in Neurosciences 28, 37-43.

15. Moon, S. I., S. Y. Eom, J. H. Kim, D. H. Yim, H. K. Kim, Y. D. Kim, and H. Kim. 2011. Thiobarbituric acid reactive substances levels in brain tissue of aldh2 knockout mice following ethanol exposure for 8 weeks. J. Life Sci. 21, 1163-1167.

16. Nordmann, R., C. Ribiere, and H. Rouach. 1992. Implication of free radical mechanisms in ethanol-induced cellular 
injury. Free Radic. Biol. Med 12, 219-240.

17. Ohta, S., I. Ohsawa, K. Kamino, F. Ando, and H. Shimokata. 2004. Mitochondrial ALDH2 deficiency as an oxidative stress. Ann. N. Y. Acad. Sci. 1011, 36-44.

18. Reinke, L. A., Y. Kotake, P. B. McCay, and E. G. Janzen. 1991. Spin-trapping studies of hepatic free radicals formed following the acute administration of ethanol to rats: in vivo detection of 1-hydroxyethyl radicals with PBN. Free Radic. Biol. Med 11, 31-39.

19. Reiter, R. J. 1998. Oxidative damage in the central nervous system: protection by melatonin. Prog. Neurobid. 56, 359-384.

20. Shin, I. S., R. Stewart, T. M. Kim, S. W. Kim, S. T. Yang, H. Y. Shin, J. S. Jung, and J. S. Yoon. 2005. Mitochondrial aldehyde dehydrogenase polymorphism is not associated with incidence of Alzheimer's disease. Int. J. Geriatr. Psychiatry 20, 1075-1080.

21. Wang, D. L., Z. Q. Ling, F. Y. Cao F. Y., L. Q. Zhu, and J. Z. Wang. 2004. Melatonin attenuates isoproterenolinduced protein kinase A overactivation and tau hyperphosphorylation in rat brain. J. Pineal. Res. 37, 11-16.

22. Yokoyama, A., H. Watanabe, H. Fukuda, T. Haneda, H. Kato, and T. Yokoyama. 2002. Multiple cancers associated with esophageal and oropharyngolaryngeal squamous cell carcinoma and the aldehyde dehydrogenase- 2 genotype in male Japanese drinkers. Cancer Epidemiol. Biomarkers. Prev. 11, 895-900.

23. Yokoyama, A., T. Muramatsu, T. Ohmori, T. Yokoyama, K. Okuyama, H. Takahashi, Y. Hasegawa, S. Higuchi, K. Maruyama, K. Shirakura, and H. Ishii. 1998. Alcohol-related cancers and aldehyde dehydrogenase-2 in Japanese alcoholics. Carcinogenesis 19, 1383-1387.

24. Yokoyama, A., T. Muramatsu, T. Omori, T. Yokoyama, S. Matsushita, S. Higuchi, K. Maruyama, and H. Ishii. 2001. Alcohol and aldehyde dehydrogenase gene polymorphisms and oropharyngolaryngeal, esophageal and stomach cancers in Japanese alcoholics. Carcinogenesis 22, 433-439.

25. Zhang, Y. W., S. H. Choi, Y. S. Kim, S. I. Moon, S. Y. Eom, Y. D. Kim, and H. Kim. 2008. Effect of ALDH2 enzyme activity on the level of 8-hydroxydeoxyguanosine in tissues following ethanol exposure. J. Life Sci. 18, 1173-1176.

26. Zhou, S., Huriletemuer, J. Wang, C. Zhang, S. Zhao, D. S. Wang, B. Wang, and X. Ma. 2010. Absent of association on aldehyde dehydrogenase 2 (ALDH2) polymorphism with mongolian Alzheimer patients. Neurosci. Lett. 468, 312-315.

\section{초록 : ALDH2 효소 활성과 8주간 에탄올 노출에 따른 해마조직의 아밀로이드 베타 발현}

문선인 $\cdot$ 엄상용 $\cdot$ 임동혁 $\cdot$ 송선호 $\cdot$ 김용대 $*$ 김헌

(충북대학교 의과대학 예방의학교실 및 의학연구소)

알츠하이머 질환은 인지능력과 행동능력 두 가지에 모두 영향을 미치는 진행적 노인성 치매증의 일종으로 정 확한 발병기전은 아직 알려져 있지 않으나 환경적 요인 및 유전적 요인이 모두 중요한 위험인자로 알려져 있다. 본 연구에서는 8 주간 에탄올에 노출된 Aldh2 knockout mouse 뇌조직을 분리하여 알츠하이머 질환의 지표로 잘 알려진 아밀로이드 베타와 NF-kB 발현을 평가하고 이러한 변화가 ALDH2 효소의 활성에 따라 어떻게 달라지는 지 비교하였다. 그 결과, 8주간 에탄올을 경구 투여한 마우스에서 ALDH2 효소의 활성에 따른 NF-kB 농도의 차 이는 확인할 수 없었으나, ALDH2 효소 활성은 알코올 노출에 의한 해마조직의 아밀로이드 베타 축적에서 중요 한 영향을 미치는 것으로 나타났다( $p<0.05)$. 이러한 결과는 $\mathrm{ALDH} 2$ 효소가 결핍된 사람이 결핍되지 않은 사람에 비해 알코올에 의한 알츠하이머 질환의 발생에 보다 민감할 수 있음을 시사한다. 